Resumen por el autor, Sante Naccarati.

Contribución al estudio morfológico de la glándula tiroides de Emys europea.

En Emys europea la tiroides es un órgano medial impar, de forma esferoidea y color rojizo, situado encima del corazón en la cavidad del arco formado por el troneo innominado. El volumen y peso de este órgano presentan considerable variaciones, que dependen en su mayor parte de la edad y tamaño del animal; el peso medio es 0.025 gramos y su longitud media $5 \mathrm{~mm}$. La irrigación sanguínea de la glándula se lleva a cabo mediante dos arterias tiroideas superiores y otras dos inferiores y el mismo número de venas. Variaciones y anomalías en el número y distribución de los vasos tiroideos son bastante frecuentes. La inervación tiene lugar mediante el vago y el simpático.

La tiroides de Emys no difiere esencialmente en estructura histológica de la de los demás vertebrados, incluso el hombre. En la cápsula de tejido conectivo fibroso existen cromatóforos esparcidos Las células del epitelio son generalmente cuboideas, menos frecuentemente cilíndricas o aplanadas y están en contacto directo con el coloide. El núcleo ocupa siempre la parte basal de la célula; es distintamente vesícular, bastante grande, provisto de gránulos cromáticos y sin nucleolo. Entre los alveolos adyacentes existen escasas fibras elásticas delicadas derivadas de las ramificaciones de la red elástica más grosera que cubre la superficie de la glándula. Los gránulos de secreción son más grandes y menos numerosos que los gránulos de grasa y las mitocondrias. Son claramente fuchsinófilos con el método de Galeotti. El coloide intravesicular no difiere del que se halla en la tiroides humana.

'Translation by José F. Nonidez

Cornell Medical College, New York 
AUTEOR'S ABETRACT OF THIS PAPER ISSUED

BY THE BIBL IOGRAPEIC SERVICE, DECEMBER 2 ?

\section{CONTRIBUTION TO THE MORPHOLOGIC STUDY OF THE THYREOID GLAND IN EMYS EUROPAEA}

SANTE NACCARATI

Department of Histology, Royal University, Rome

FIVE COLORED FIGURES

NOTES ON THE EMBRYOLOGY OF THE THYREOID

The thyreoid, together with the thymus, the postbranchial or suprapericardial bodies, the carotid gland, the thymous lobules, and the parathyreoids (also called epithelial corpuscles), belongs to the group of organs called branchial derivatives.

The first embryogenetic researches on the thyreoid go back to Huschke ('26), Rathke, Remak ('55), and Götte ('67) and, with many others which followed not long after, were conducted almost exclusively on mammals. They served to establish that the thyreoid is derived from a thickening and hollowing of the ventral wall of the pharynx at the level of the second pair of branchial arches.

His ('68) established that the thyreoid is derived from two equal lateral rudiments in the pharyngeal wall.

Müller ('71), Sessel ('77), and Kölliker ('79) found that in mammals the thyreoid is derived from a single medial rudiment in the form of a hollow diverticulum (Müller and Seessel) or of a solid bud (Kölliker) from the ventral wall of the pharynx, with which it remains in temporary connection.

Born ('83) and Fischelis ('85) found that in the pig embryo the thyreoid comes from three rudiments, originally independent, a middle thyreoid rudiment arising from the ventral wall of the pharynx at the level of the second pair of branchial arches, and two lateral thyreoid rudiments, supposed to be formed from the epithelium of the fourth entodermic branchial pouches. 
Other researches were conducted by Wölfer ('80), Stieda ('81), Dohrn ('87), Götte ('75), DeMeuron ('86), Maurer ('85), Balfour ('78), Kastschenko ('87), Piersol ('88), Prénant ('94-'99), Van Bemmelen ('85-'93), Platt ('96), Simon, Soulié ('97), Verdun, Jacoby ('94, '96, '97), Verson ('07), and others more recently, too many to be quoted here, with resulting confirmation of the origin of the thyreoid from three distinct and originally independent rudiments, i.e., one middle and two lateral thyreoid rudiments, in mammals.

According to Maurer ('99) Echidna, and according to Symington ('97, '98) the Edentata and Marsupialia are exceptions to this rule, in that they retain the independence, of the three rudiments, having, in addition to a two-lobed thyreoid, two organs developed from the lateral rudiments, homodynamic with the postbranchial or suprapericardial bodies, by which name they are called.

Livini ('02) made a careful study of the embryology of the organs of the thymus-thyreoid system in Amphibia urodela, and found the thyreoid arises as a single medial solid epithelial bud from the caudal wall of an entodermic spur of the pharyngeal floor which enters in intimate contact with the ectoderm. He considers this spur as a rudiment of the hypobranchial groove of the Tunicata. However, the level at which the thyreoid arises cannot be established because when its bud is already recognizable, neither the branchial pouches nor the cartilages of the branchial arches have yet been differentiated.

\section{NOTES ON THE COMPARATIVE ANATOMY OF THE THYREOID}

Cyclostomata. In the lamprey the thyreoid gland is but little developed in the adult. In the larvae (Ammocoetes) it remains in open communication with the buccal cavity, at a level between the third and the fourth branchial slit, in such a manner that it may be considered as a diverticulum of the ventral wall of the pharynx. With the coming of the metamorphosis it becomes a glandular organ of vesicular structure and is isolated from the pharynx. The arrangement in the larvae recalls a homologous relation between the thyreoid in the 
Cyclostomata and the hypobranchial groove of Amphioxus, on the one hand, and between the latter and the ventral furrow of the branchial basket in the Tunicata on the other. This homology is based on the following considerations:

I. The thyreoid of Petromyzon in the Ammocoetes stage is a sort of muciparous gland, which, if it in some respects differs from the endostyle of the Tunicata, nevertheless presents such points of resemblance to it that the two formations may be regarded as homogeneous (Dohrn, '80).

II. During the development this gland is transformed into an organ corresponding to the thyreoid of other vertebrates.

In the Elasmobranchii the thyreoid is a single medial organ sometimes spherical, sometimes cylindrical, sometimes triangular or pear-shaped; its volume and weight differ in different animals; sometimes (as in Scyllium catulus) it is cranially located at the angle of bifurcation of the branchial artery; sometimes it is located in the vicinity of the tongue, between the coracohyoideal and coracomandibular muscles (as in Acanthias vulgaris and in Mustelus laevis); sometimes it is immediately under the skin (as in Squatina angelus).

Within the thyreoid of the Elasmobranchii there exist, according to Thompson ('10), masses of small solid cells, partly epithelial, partly adenoid, which have been thought to indicate a homology with the parathyreoids and the thymus.

In the Teleostei, according to Maurer ('85), the thyreoid is a single organ until, at a certain age, it divides into an accumulation of follicles which surround the branches of the branchial artery on every side. 'In Amiurus, according to Thomson, the thyreoid consists of a number of vesicles scattered here and there, enclosed in the matrix of the connective tissue; the cells which line the vesicles are cylindrical, very low, and in some cases almost flat.

In the Urodela the thyreoid is a double organ, yellowish in color, spherical or egg-shaped; its largest diameter is less than $1 \mathrm{~mm}$; it is slightly flattened, and very superficially located, between the mylohyoid and sternothyreoid muscles, in the immediate vicinity of the jugular vein. 
In the Anura, also, the thyreoid is a double organ (single in the embryo), lateral, egg-shaped, pinkish in color; each half is $4 \mathrm{~mm}$. in diameter; both are located in the ventral side of the animal, at the posterior horns of the hyoid bone, in front of the jugular veins, to which they are closely adherent.

In the Ophidia the thyreoid is a single discoidal organ located in the median line at the base of the heart, between the two carotids in the young animal it is at the lower extremity of the thymus. Its diameter is about $3 \mathrm{~mm}$. and its weight about $2 \mathrm{mgm}$.; by its grayish-white color it is easily distinguished from the two thymous lobes, noticeable for their brighter color, whose medial margins cover it.

In the Lacertilia also (aside from a few genera like Monitor, in which it consists of two lobes located at the side of the neck in front of the carotids) the thyreoid is a single medial organ just under the skin on the ventral side of the trachea, along which it lies with its.greatest diameter transverse to the diameter of the trachea. It is dark gray; fusiform, largest in the middle, the two extremities narrowing until, as they reach the lateral extremities of the neck, they terminate in a fine filament, often bifurcated. In the Lacerta viridis it reaches a length of $1 \mathrm{~cm}$.

My research on the thyreoid in the Squamata, on the species Zamenis viridiflavus, Tropidonotus natrix, Lacerta viridis, and Lacerta agilis, confirming this statement, will form the subject of another paper.

In the Aves the thyreoid consists of two rounded or oval lobes, pink in color, varying in size with the animal, and located at the sides of trachea near the syrinx, attached to the ventral side of the carotid, generally at the level of the vertebral artery. In the pigeon, for example, the thyreoids occur in the anterior wall of the thorax, near the junction of the thorax and neck. They are ovular in form, with their longest diameter lengthwise of the body; their lowest point is slightly above the point where the main branches of the carotid artery divide. In front of them are the jugular veins on the outside and the oesophageal arteries on the inside. 
Mammalia. Aside from the human thyreoid, the detailed description of which may be found in any treatise on anatomy, it may be remarked that in manral, this organ in mammals consists of two lateral lobes at the sides of the trachea, between the first and the ninth tracheal rings-the exact position depending on the animal; the weight and volume also vary with the animal.

In general the two lobes are joined to each other by an isthmus, usually thin, as in the dog, cat, rabbit, rat, and guinea-pig; in old animals it may atrophy or disappear. Thus in the donkey the isthmus is easily seen in the young animal, while in the old it is reduced to a slight atrophic filament without glandular structure. In the horse and sheep, on the other hand, the isthmus is so thin that often it cannot be distinguished; this has led some to believe that in these animals it occurs only exceptionally. Aberrant nodes of thyreoid tissue have been described in nonhuman mammals; in these, however, it has not been possible to recognize the pyramid of Lalouette or the appendix of Morgagni.

\section{PERSONAL INVESTIGATIONS}

My researches on the thyreoid of Chelonia were carried out on the two Italian species, Emys europaea and Testudo graeca. There is very little difference in the macroscopic aspect and no difference at all in the microscopic appearance of the thyreoid in these two species. I will give the description of the thyreoid of Emys europaea and refer to Testudo graeca for the main differential points.

Macroscopic anatomy. In Emys europaea the thyreoid is a single medial organ of spheroid form and pinkish color, located in the cavity of the arch formed by the truncus innominatus. From the anatomic-topographic point of view, in order to reach the thyreoid by trepanning it is necessary to apply the point of the instrument half a centimeter above the point of union of the hyoplastral with the hypoplastral plates. Removing the bone, and taking pains to hold the animal's forepaws well apart so as to withdraw from the operative field the two scapuloclavicular ligaments (with the animal's neck extended), one finds a small 
rounded body, easily recognized by its pink color, across the adipose tissue and suprapericardial connective tissue, larger or smaller than a pea according to the size of the animal.

In the classic treatise of Bojanus (1819-21) in which are reported with clearness and precision all the characteristics of the macroscopic anatomy of Emys europea, the thyreoid is taken for the thymus. The latter, when it exists, is a long double organ of a light gray color, located in front of the carotids, with which it is in close contact, at the point of conjunction of the neck with the thorax. It is strange that so able an anatomist should have fallen into such an error. The pink color of the thyreoid is due to the blood which it contains, the amount of which is very considerable (according to Tschuovsky, $560 \mathrm{cc}$. of blood pass each minute through 100 grams of human thyreoid tissue). When the excess of blood in the thyreoid of the tortoise is eliminated, it acquires the appearance of an opalescent lens.

Volume and weight. The volume and weight of the thyreoids of Emys europaea are very variable. The most noteworthy variations are due to the size and age of the animal. With the purpose of establishing as exactly as possible the average weight, I have weighed the thyreoid of thirty Emys and found that in adults weighing about $275 \mathrm{gm}$. the thyreoid has an average weight of $0.025 \mathrm{gm}$. In general, $100 \mathrm{gm}$. of body weight corresponds to about $10 \mathrm{mgm}$. of thyreoid. 'For man this proportion is about five times as big. If the weight of the Emys is taken without its carapace and plastron, which averages about 40 per cent of the total, according to my measurements of thirty animals, the proportion is $16 \mathrm{mgm}$. of thyreoid to $100 \mathrm{gm}$. of the animal's weight. There are great individual variations from the average. In another paper I have prepared, in tabulated form, the weights of the thyreoid and other glands in groups of several species of reptiles, including Emys europaea.

As regards the volume of the thyreoid in Emys europaea, what I have said regarding the weight holds good, namely, that it varies within very wide limits, according to the size of the animal. In general it may be stated that in an animal of $300 \mathrm{gm}$. weight, the maximum diameter of the gland is about $5 \mathrm{~mm}$. 
Topographical relations. As I have said above, the thyreoid in Emys europaea lies within the large upward-curving arch formed by the truncus innominatus, just above the heart. As this arch leans slightly toward the right, the gland is not absolutely in the middle, but is a little to the right. In front (on the animal's ventral side), the thyreoid is separated from the thoracic wall by a lamellar connective, transparent and fairly tough, consisting of several layers, continuous below with the pericardium and surrounded above by the large vessels of the neck. The vascular arch along which the thyreoid lies is closely connected with it, both by means of the vessels and by means of the connective tissue. The rear wall of the gland (toward the animal's dorsal side) is in front of the trachea, with which it is not in contact. It must be noted that in Emys europaea the trachea divides into the two bronchi a little above the thyreoid, while in Testudo graeca the division occurs much higher, near the base of the tongue.

Circulation and innervation. As in a man, the thyreoid in these Chelonia is highly vascularized. The blood flows to it through the two superior and the two inferior thyreoid arteries. The inferior pair are short, but very capacious; they issue from the truncus innominatus, and penetrate the gland at right angles, passing through its outer inferior margin. Regarding the behavior of the large vessels as they leave the heart, it should be remembered that, whereas the left aorta reaches the left bronchus without branching, the right aorta on the contrary, before curving, sends off a large but very short trunk (truncus innominatus) which forms a superior concavity and then divides into the right and left carotid and subclavian arteries, after sending off the inferior thyreoid arteries and the oesophageal arteries.

The superior thyreoid arteries are longer but thinner; they branch from the carotids and turn downward and inward, issuing in the outer superior margin of the thyreoid gland. These arteries (unlike the inferior thyreoid arteries which are always present) are sometimes missing.

It must be noted that the division of the truncus innominatus into subclavian and carotid sometimes occurs a little higher on 
the right than on the left; when the animal's neck is extended, the point of bifurcation of the two carotid arteries and the right subclavian is in a line with the right forepaw.

In connection with the thyreoid arteries it must be noted that there are many variations, especially of the superior pair, which often, instead of penetrating the gland directly, join the inferior pair, thus entering the gland as a single trunk. When this occurs, the superior thyreoid artery turns downward immediately after leaving the carotid and follows a course of about $1 \mathrm{~cm}$., while the inferior artery, turning slightly upward, follows a very short course. The trunk which results from their union is so short and thick that it resembles an arterial sinus.

At other times the superior thyreoid artery is missing, and is replaced by three or four small arteries forming a network around the upper tip of the gland. At still other times there may be a median artery which arises from one of the two carotids near the hyoid bone and turns downward along the median line of the neck, reaching the upper tip of the gland.

The ramifications of these arteries, finely divided, form a plexus around the fibrous capsule which surrounds the gland, and penetrate the parenchyma, where they form a very fine capillary network interwoven with the thyreoid vesicles, which they enclose, passing through the intervesicular septa. The musculature of these vessels is very distinct.

The veins which originate in the form of fine branchlets traversing the vesicles compose on the surface of the gland a thick venous network, a large plexus from which issue the principal veins (inferior thyreoid); the latter unite with the accessory pectoral veins and empty into the subclavian vein formed by the confluence of the jugular and axillary veins.

The fine perivesicular veins are without musculature and appear as little tubes with endothelium alone, traversing the interlobular connective tissue. Fine elastic fibers passing through this tissue seem to provide a kind of support for the larger vessels. The lymphatics are also very numerous; as in human thyreoid, they arise as small vacuoles between the cells lining the vesicles; these unite to form intervesicular canals, and those in 
turn join to form larger trunks (the interlobular canals). These last follow the course of the arteries, veins, and nerves till they reach the external surface of the gland, where they form a dense network, from which emerge the larger branches through which the lymph is emptied into the lymphatic ganglia of the neck.

The innervation of the thyreoid is by the sympathetic. The fine non-medullated fibers accompany the arterial ramifications in the gland. The vagus also sends two fine branchlets into the gland through the laryngeal nerves, but their distribution is not constant.

\section{HISTOLOGY}

For the microscopic study of the thyroid of Emys europaea I have made use of specimens preserved in-

1. Formalin, from 5 per cent to 10 per cent aqueous solution.

2. Mercuric chloride

3. Zenker's fluid

4. Flemming's fluid

5. 96 per cent alcohol

6. Müller's fluid

The sections were stained in different ways. For the general study of the thyreoid tissue, preservation in 10 per cent formalin and staining with Ehrlich's acid-haematoxylin and the aqueous solution of eosin gave good results. Fixation in Flemming and staining with ferric haematoxylin (Heidenhain) and eosin permitted greater accuracy in studying the delicate structure of the cellular elements. Safranin and carmine have been very useful in delicate cytological study. For studying the elastic fibers fucselin and Weigert's fluid were used combined as follows:

$a$. Fucselin.

$b$. Fucselin-Van Gieson: Weigert's fluid.

c. Weigert's fluid; borax carmine, alcoholic solution of the Naples Zoological Station.

d. Weigert's fluid safranin.

e. Safranin, picric acid, Weigert's fluid.

There is no substantial difference in structure between the thyreoid of Emys europaea and Testudo graeca and that of the 
other vertebrates, including man. It presents externally a fibrous connective-tissue capsule in which, here and there, are scattered pigmented cells (chromatophores). From this capsule issue numerous connective-tissue septa, which, gathering on the inside of the gland, form a network enclosing the vesicles. These vesicles, called also follicles or alveoli, are irregularly rounded, from $50 \mu$ to $300 \mu$ in size, and are lined with simple epithelium, the cells of which are mainly cubical, less often cylindrical or flat, and are in direct contact with the interior of the vesicular cavity, in which is contained the colloidal fluid, an amorphous, homogeneous substance presenting under the microscope transverse streaks or fissures and staining with acid stains; for example, it stains pink with haematoxylin-eosin and yellow with Van Gieson or with safranin and picric acid. The interior surface of the epithelial cells, namely, the surface looking in the lumen of the vesicles, is not clearly defined, but it has a broken appearance, recalling that of the colloidal substance, and probably, since it is not constant, due to the latter's remaining adherent to the cells. The protoplasm is homogeneous and contains fine grains. The nucleus always occupies the basal part of the cell, is well marked, vesicular, rather large, and provided with chromatin granules and does not have a nucleolus. The limits between the cells are quite clear, and in the cellular walls, which are in contact with the connective tissue limiting the alveoli, there is a basal membrane, not always, however, well differentiated. In specimens colored with safranin and picric acid there are cells having a nucleus which contains granules colored red (chromatin) noticeable against the brighter background of the rest of the nucleus, and cells whose nucleus is entirely colored red (fig. 3). These two kinds of cells correspond to the two types, principal and colloidal, described by Langendorff, who interpreted them as different aspects assumed by the same cell at different functional periods. This interpretation seems very probable because the aspect and the disposition of the cells in the different alveoli is so variable that they suggest many functional phases from the beginning elaboration to the complete secretion of the colloid. 
The gland is subdivided into lobules by larger connectivetissue septa derived from the external fibrous-connective capsule, and the lobules in their turn are subdivided into alveoli by thinner septa of the same nature. The blood vessels, the lymphatics, and the nerves run into the intervesicular and interlobular septa, where they form a highly complicated network. In the small thyreoid arteries I have not found it possible to demonstrate those thickenings or buds (Schmidt's 'Zellknospen') of which Kölliker ('02) speaks. The intervesicular substance is rather scanty, and is formed of areolar connective tissue, extremely rich in blood vessels, which constitute a capillary net surrounding the alveoli and extending its finest branches into the epithelium. Between each alveolus and the next are scanty delicate elastic fibers which accompany the blood vessels and are derived from the ramifications of the coarser elastic network covering the surface of the gland. The elastic fibers are numerous and well demonstrable only in the external connective capsule. Toward the interior of the gland they grow thinner and scarcer till they disappear entirely in the walls of the most central of the alveoli. Elastic fibers are more frequent in the thyreoid of young animals.

Under the microscope the intravesicular colloid does not differ essentially from that of the human thyreoid. In the interior of the alveoli there are, at times, free epithelial cells, detached from the alveolar walls, as if some cellular desquamation had occurred (fig. 3). This condition noted in the thyreoid of individuals suffering from Basedow disease was at first given a pathological significance; later it was seen that it was a normal phenomenon, a form of holocrine desquamation of certain thyreoid cells (Pende, '18).

The granules of secretion, as in the cells of the human thyreoid, appear larger and less numerous than the granules of fat and the mitochondria. They stain distinctly red (fuchsinophile) with the method of Galeotti. This method, proposed by Galeotti for the study of the granules of secretion, is of the utmost importance for finer cytologic researches and should never be omitted. The fixative for the employment of this method is either Flemming's 
or Hermann's fluid. The sections must be very thin, about 4 or $6 \mu$.

The technique is as follows:

1. The section is stained from five to ten minutes at the temperature of $50^{\circ} \mathrm{C}$. with a freshly prepared saturated solution of fuchsin in aniline water.

2. Wash in water for about thirty seconds.

3. Transfer to a semisaturated solution of picric acid in 50 per cent alcohol for twenty or thirty seconds.

4. Prolonged wash in water until the section does not yield any more picric acid.

5. Staining for four or five minutes with a $\frac{1}{2}$ per cent solution of methyl green in 90 per cent alcohol.

6. Rapid transfer to grades of alcohol, during which the sections yield much stain.

7. Transfer to xylol and mount.

Sections thus prepared show the following characteristics: The nuclear chromatin, the centrosomes, and the granules of secretion are bright red, the protoplasm and the connective green. The strongly basophile substances, such as mucin and chondrin, take also a green, but more intense stain. The picric acid, acting as a mordant on the methyl green, renders it a plasma dye. In good sections the plasma takes an emerald green stain. If it takes a yellowish-greenish stain, the section can be utilized, provided that the fuchsinophile granules take a distinctly bright red stain. Sometimes (either because of a much prolonged action of the picric acid or for other reasons) the section does not stain at all with methyl green. It is advisable to repeat this method several times until a good section is obtained.

Figure 4, showing only a part of the epithelium of the vesicle, gives the appearance of a few cells stained with the method of Galeotti. 


\section{BIBLIOGRAPHY}

BALFoUR, F. M. 1878 A monograph on the development of elasmobranch fishes. London.

BojanUs 1819-21 Anatome Testudinis europeae. Vilna.

Bons, G. 1883 Ueber die Derivate der embryonalen Schlundbogen und Schlundspalten bei Säugethieren. Arch. mikr. Anat., Bd. 22.

DoHrs, A. 1886 Studien, usw. VIII. Die Thyroidea bei Petromyzon, Amphioxus und den Tunicaten. Mitth. Zool, Sta. Neapel, Bd.6. 1886-7 Studien, usw. XI. Thyreoidea und Hypobranchialrinne. Mitth. Z.S. Neapel, Bd.7.

Fischelis, Ph. 1885 Beiträge zur Kenntnis der Entwickelungsgeschichte der Glandula thyreoidea und Gl. Thymus. Arch. mik. Anat., Bd. 25.

GoerTe, A. 1867 Beiträge zur Entwickelungsgeschichte des Darmkanals des Hünchens. Tübingen. 1875 Die Entwickelungsgeschichte der Unke. Leipzig.

HIs, W. 1868 Untersuchungen über die erste Anlage des Wirbelthierleibes. Leipzig.

1880-85 Anatomie menschlicher Embryonen. Leipzig. 1889 Schlundspalten und Thymusanlage. Arch. Anat. u. Physiol., Anat. Abth.

1891 Der Tractus thyreoglossus und seine Beziehung zur Zungenbein. Arch. Anat. u. phys., Anat. Abth.

Huschke, E. 1826 Ueber die Umbildung des Darmcanals und der Kiemen der Froschquappen. Oken's Isis, Bd. 1.

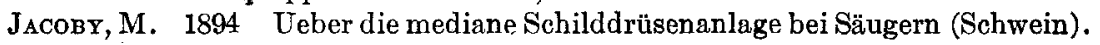
Anat. Anz. Bd., 10.

1896 Ueber die Entwicklung der Nebendrüsen, der Schilddrüsen und der Carotiddrïsen. Anat. Anz., Bd. 12.

1897 Zur Entwickelung der Nebendrüsen. Anat. Anz., Bd. 13.

Kastschenko, N. 1887 Das Schicksal der embryonal Schlundspalten bei Säugethieren Arch. f. mikr. Anat.,, Bd. 30.

1887 Das Schlundspaltengebiet des Hünchens. Arch. Anat. u. Entw., Anat. Abth.

KöLLIKER, A. 1879 Entwickelungsgeschichte des Menschen und der höheren Thiere. Leipzig.

1902 Handbuch der Gewebelehre des Menschen. Leipzig.

Livini, F. 1902 Organi del sistema timotiroideo nella Salamandrina perspicillata. Arch. Ital. Anat. e Embriol., T. 1

Mavrer, F. 1885 Schilddrüse und Thymus der. Teleostier. Morph. Jahrb. Bd. 11.

1888 Schilddrüse, Thymus und Kiemenreste der Amphibien. Morph. Jahrb., Bd. 13.

1898 Der Derivate der Schlundspalten bei der Eidechsen. Verh. Anat. Gesellsch., Bd. 12.

1899 Schlundspalten Derivate von Echidna. Verh. Anat. Gesellsch., Bd. 13.

1899 Die Schilddrüse, Thymus und anderen Schlundspalten Derivate bei der Eidechse. Morph. Jahrb., Bd.27. 
de Meuron, P. 1886 Développement du Thymus et de la glande thyreoïde. Arch. d. Sci. Phys. et Nat., Geneve, T. 14.

MülleR, W. 1871 Ueber die Entwickelung der Schilddrüse. Jena. Zeitsch., Bd. 6.

Pende, N. 1918 Endocrinologia. Milano.

Piersol, G. M. 1888 Ueber die Entwickelung der embryonal Schlundspalten und ihrer Derivate bei Säugethieren. Stzber. phys. med. Gesellsch., Würzburg.

PLATT, J. 1896 The development of the thyroid gland and of the suprapericardial bodies in Necturus. Anat. Anz., Bd. 11.

Prénant, A. 1894 Contribution a l'étude du développement organique et histologique du thymus, de la glande thyreoïde, et de la glande carotidienne. La Cellule, T. 10.

1896 Élements d'embryologie de l'homme et des vertebrés. Paris.

1896 Sur le développement des glandes accessoires de la glande thyroide et celui de la glande carotidienne. Anat. Anz., Bd. 12.

1898 Sur les dérivés branchiaux des Reptiles. Bibliog. Anatom., T. 6 , fasc. 5 .

1899 Rectification au sujet de la communication de M. Maurer: "De Schlundspalten Derivate von Echidna. Anat. Anz., Bd. 16.

Les dérivés branchiaux chez l'orvet. Arch. Anat. norm. et. path., Ve. Ser., T.8.

RathKe, H, 1828 Ueber die Entwicklung der Athmungswerkzeuge bei den Vögeln und Säugethieren. Nova Acta, 14 (quoted by Wölfler).

REMAK, R. 1850-55 Untersuchungen über die Entwicklung der Wirbelthieren. Berlin.

Seeser, A. 1877 Zur Entwickelungsgeschichte der Vorderdarms. Arch. Anat. u. Physiol.

Sodlié et VeRdun 1897 Sur les premières stages du développement de la thyroide mediane. C. r. Soc. Biol. de Paris.

STIEDA, L. 1881 Untersuchungen über die Entwicklung der Glandula thymus, Thyreoidea und carotica. Leipzig.

Symivgton, J. 1897 Ueber Thyreoidea, Glandulae parathyreoidea und Thymus beim dreizehingen Faultier. Arch. Anat. u. Physiol., Anat. Abt.

Symroton, J. 1898 The thymus gland in the Marsupialia. Jour. Anat. and Physiol., vol. 32.

Thоmpson, F. D. 1910 The thyroid and parathyroid glands throughout vertebrates. Phil. Trans. R. Socy., 201 B.

Verdun, P. 1896 Sur les glandes satellites de la thyroidde du chat les kystes qui en dérivent. C. r. Soc. Biol. Paris, T. 48.

1897 Sur les dérivés de la quatrième poche branchiale chez le chat. ibid., T. 49.

1898 Sur les dérivés branchiaux du poulet. Ibid., T. 50.

1898 Glandules branchiaux et corps post-branchiaux chez les Reptiles. Ibid., T. 50.

1898 Dérivés branchiaux chez les vertebrés superieurs. Toulouse.

Évolution de la quatrième poche branchiale et de la thyroĩde laterale chez le chat. Jour. Anat. et Phys., T. 34. 
Van Bemmeln, J. F. 1885 Ueber vermuthliche rudimentäre Kiemenspaiten bei Elasmobranchiern. Mitth. Zool. Sta. Neapel., Bd. 6.

1893 Ueber die Entwickelung der Kiementaschen und der Aortabogen bei den Seeschildkröten untersucht an Embryonen von Chelonia viridis. Anat. Anz., Bd. 11.

Verson, S. 1907 Contributo allo studio della ghiandolo tiroide ed annessi. Arch. Sci. Mediche, Torino, T. 31.

Wötfler, A. 1880 Ueber die Entwicklung und Bau der Schilddrüse. Berlin. 


\section{PLATE 1}

\section{EXPLANATION OF FIGURES}

1 Thyreoid of Emys europaea. Fixation: alcohol 96 per cent. Staining: alcoholic carmine solution of the Zoological Station of Naples, Weigert's fluid picric acid. $8^{*}$ objective, 4 ocular. The colloid is stained yellow, the cellular nuclei red, the elastic fibers blue. A portion of the external capsule has been left in place. Note how numerous are the elastic fibers in the capsule and how extremely scarce are they in the intervesicular connective.

2 Same. Fixation: Flemming's fluid. Staining: Heidenhain's haematoxylin. $7^{*}$ objective, 4 ocular. In some places the intervesicular connective has given way and the alveoli appear detached. 

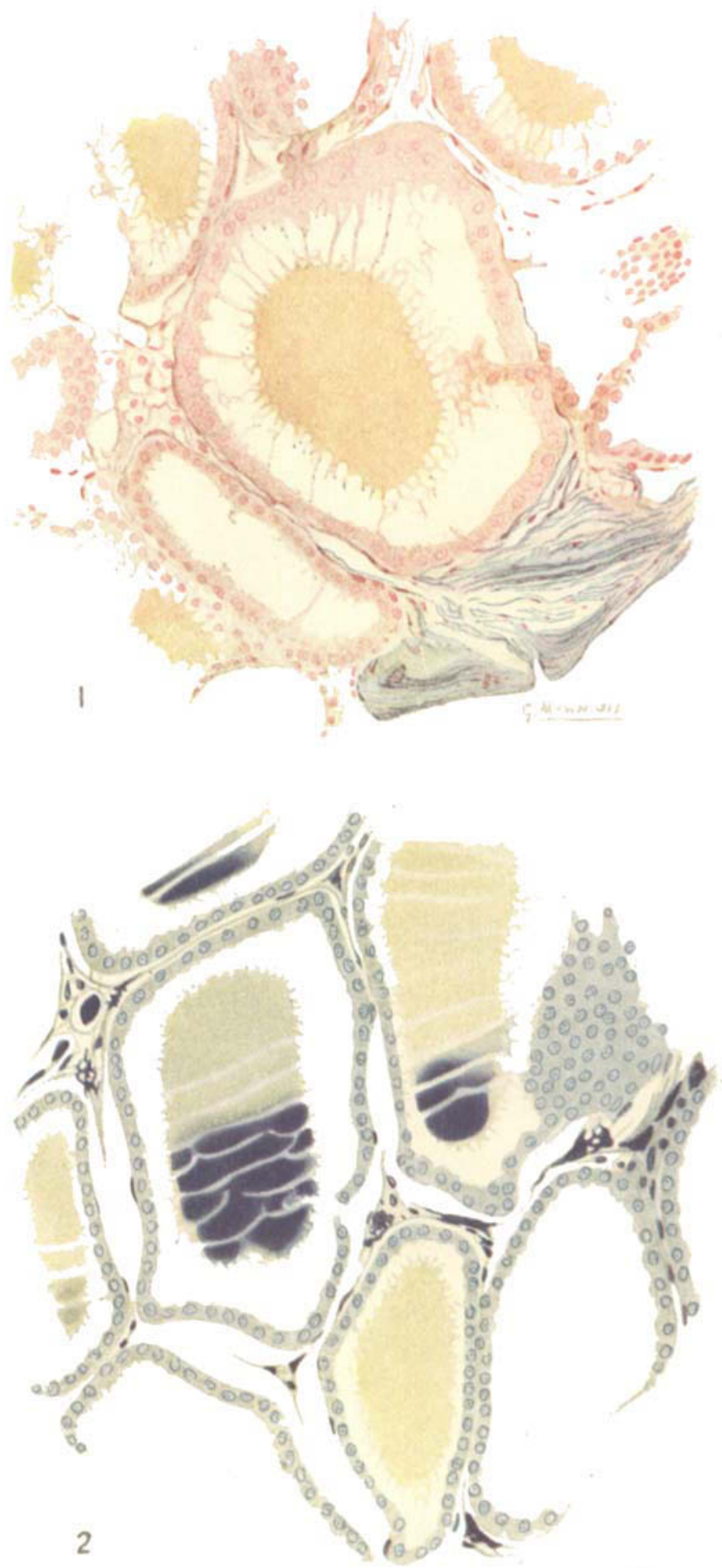
PLATE 2

EXPLANATION OF FIGURES

3 Same. Fixation: Flemming's fluid. Staining: Safranin-picric acid. 1/15 Imm., ocular 4. The two different aspects of the thyreoid cell, viz., the principal and the colloidas celis, are distinctly shown. Some cells detached from the epithelium are shown in the colloid.

4 Same. Fixation: Flemming's fluid. Staining: Galeotti's method. 1/15 imm., ocular 4. Only a part of the section has been drawn, in order to demonstrate the granules of secretion within the cell bodies.

5 Same. Fixation: Formalin. Staining: Haematoxyin and eosin. Objective, Zeiss BB, ocutar 4. An island of thymus substance was found in the thyreoid of this animal and is shown in this section. 


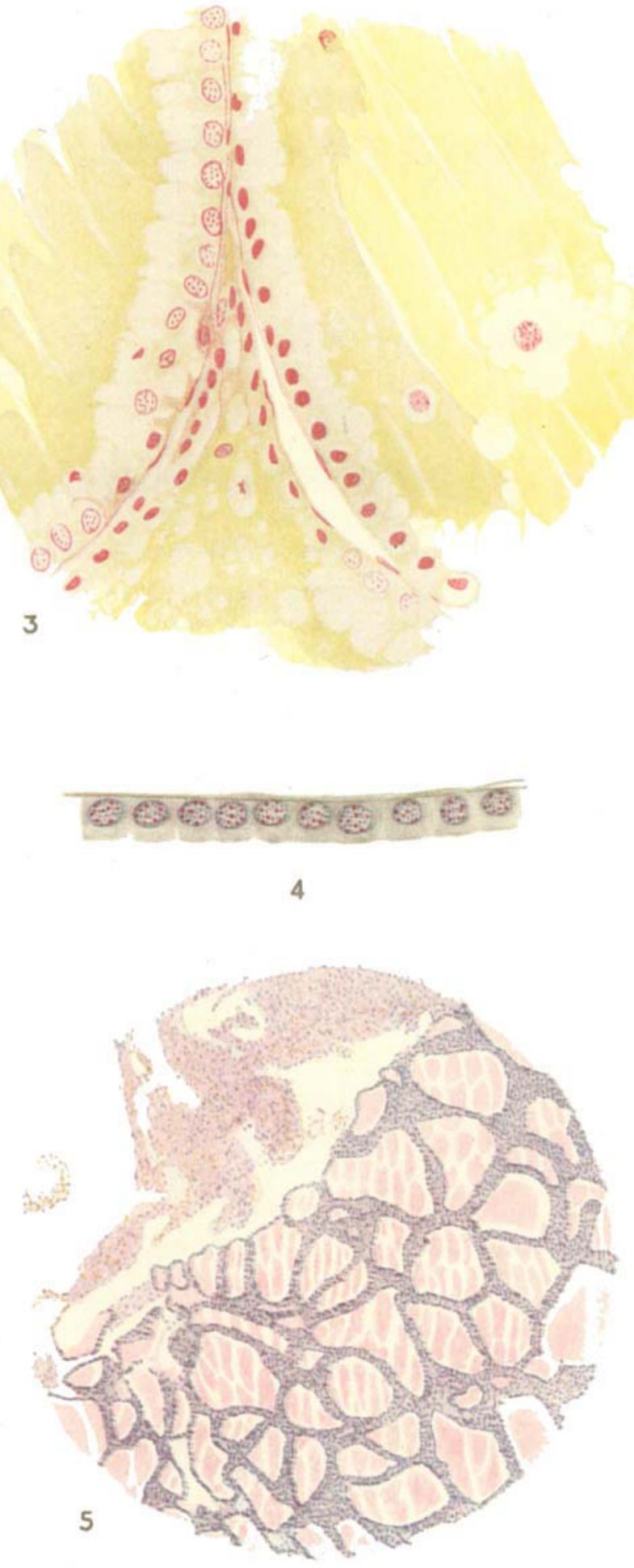

